${ }^{0}$ Entomologica Fennica. 8 May 2000

\title{
On the occurrence of the genus Hyperaspis (Col. Coccinellidae) in Fenno-Scandian countries.
}

\author{
Tom Clayhills
}

Clayhills, T. 2000: On the occurrence of the genus Hyperaspis (Col. Coccinellidae) in Fenno-Scandian countries. - Entomol. Fennica 11: 109-112.

The distribution of the species of Hyperaspis occurring in northern Europe, $H$. pseudopustulata and $H$. inexpectata is discussed and the confusion concerning $H$. reppensis based on old traditional determinations in our countries is straightened out. $H$. reppensis does not occur in northern Europe. $H$. concolor is reported from Sweden as new for the Fenno-Scandian countries.

Tom Clayhills, Zoological Museum, Centre for Biodiversity, University of Turku, FIN-20014 Turku./contact address:Tennbyntie 33-35, B4, FIN-21600 Parainen, Finland

Received 8 March 1999, accepted 28 February 2000

\section{Introduction}

For a long time Hyperaspis reppensis (Herbst, 1783) was considered to be the only species of the genus occurring in the northern countries, Denmark, Norway, Sweden and Finland, as well as the north western parts of Russia (Lindroth 1960).

In 1959 Günther published a thorough investigation on the genus in Czechoslovakia and described the new species $H$. inexpectata Günther,1959 which was announced later also from Finland (Clayhills \& Rutanen 1987). He also pointed out the differences between $H$. reppensis and $H$. pseudopustulata Mulsant, 1853, which led to the withdrawal of the former species from Denmark and Norway (Hansen. V, 1969, Hansen. M, 1987, Lundberg 1986). It was replaced in both countries by $H$. pseudopustulata which was also later recorded from Sweden (Lundberg 1995). But up till now $H$. reppensis has been considered the most widespread species in Sweden and Finland with a distribution area from Sk to Lu.lpm in Sweden (Lundberg 1995) and from Ab to Om in
Finland (Lindroth 1960). Lindroth also mentions $H$. reppensis from $\mathrm{Kl}, \mathrm{Ksv}$ and $\mathrm{Kk}$ in the Karelian part of Russia. In both countries, however the species is considered rare.

In the summer of 1996 while collecting beetles from the Isle of Örö, Ab:Dragsfjärd, in the south western part of Finland I came across 14 Hyperaspis specimens, 8 of which were males. They were easily determined, for instance by genital characters, as belonging to $H$. pseudopustulata. That led me to cheque the old material first from Finland including the Karelian parts of the USSR and later also from Sweden.

\section{Diagnostic characters}

Both Günther (1959) and Fürsch (1992) give good descriptions of the species occurring in the northern countries, vs $H$. pseudopustulata and $H$. inexpectata, with good pictures of the male genitals. They also point out the differences between these and the real $H$. reppensis, the distribution area of which lies mainly in the eastern parts of central 
and southern Europe with South eastern parts of Germany, Poland, Tschechoslowakia and Austria (Lucht, 1992). H. reppensis is mainly a Pusta species with the main distribution area in the Hungarian Pusta and eastward. Due to the confusion of the two species present-day details of the distribution are, however, not totally reliable, a situation already pointed out by Günther. Günther (1959) as well as Fürsch (1992) separate males of H. pseudopustulata, in their keys, from the other two species by the presence of the yellow humeral spot or stria which the other two should lack. But that is not true for $H$. inexpectata, males of which every now and then have a vague reddish brown narrow humeral stria but, as far as I have seen, never a conspicuous yellow triangular spot which is typical for H. pseudopustulata. It is worth mentioning that these colour characters only concern males of the genus. For male genital differences see Günther (1959) and Fürsch (1992).

In the material from Sweden there is however, one specimen in coll. Mus. Zool. Lund, a + , and another in coll. Gothemb. Nat. hist. Mus. a $\sigma^{\star}$, both taken from Halland Fjärås that clearly belong. to the species $H$. concolor Suffrian 1843, a new species for the Fenno-Scandian area. It was long considered a black form of $H$. campestris (Herbst, 1783) and later described as H. concolor by Suffrian. Günther (1959) considered it "a forma" but in 1985 Canepari et al. point out clear differences between $H$. campestris and $H$. concolor and give it, quite correctly a status of a valid species. In the northern countries it resembles most $H$. inexpectata by the round form but is quite easy to identify by the completely black elytras of the female and the faint humeral stria of the male while $H$. inexpectata always seems to have at least a faint, mostly clear yellow preapical spot on each elytron. Also the male genitals are different.

The three species occuring in Fenno-Scandian countries can be identified sa follows:

1. Elytrons, with the exception of the small humeral stria by the male black, form almost spherical H. concolor (Fig. 1) -Each elytron with a yellowish preapical spot 2

2. Form spherical, very convex, the humeral striae of the male usually lacking, when present faint, the preapical spots usually smaller .....

H. inexpectata (Fig. 2)

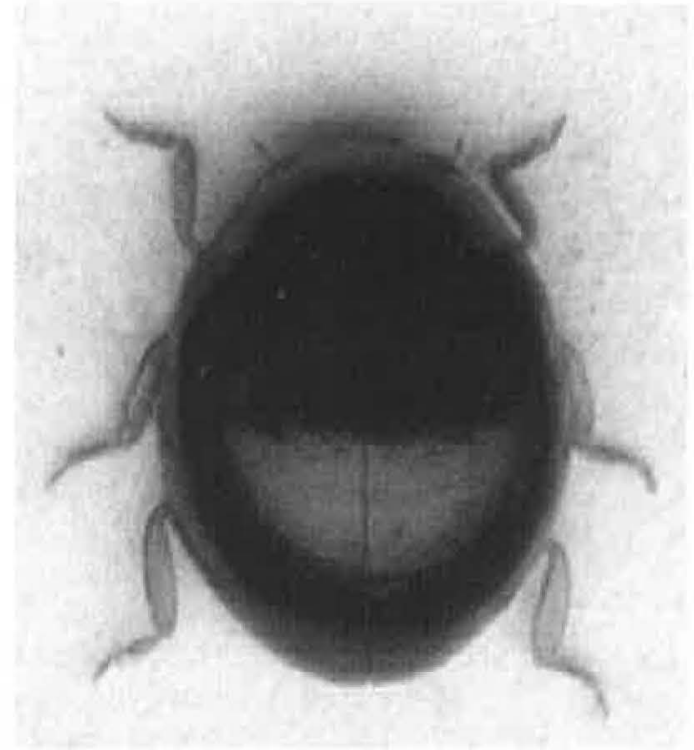

Fig. 1. Hyperaspis concolor Suffrian, 1843. $\sigma^{7}$

-Form oval, clearly flattened, the humeral spots of the male clear, triangular, preapical spots ${ }^{1}$ usually bigger ... H. pseudopustulata (Fig. 3)

Among the northern species H. pseudopustulata can also be recognized by the robust tibiae, especially seen on the hind ones which are clear-

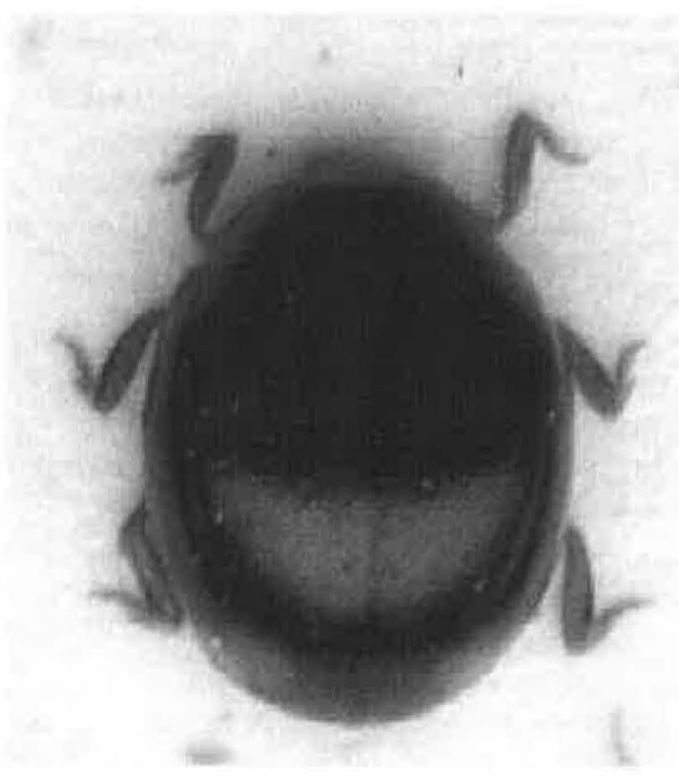

Fig. 2. Hyperaspis inexpectata Günther, 1959. 우

'Among about 200 specimens of $\mathrm{H}$. pseudopustulat examined, two males lacked the preapical spots but they differ from $\mathrm{H}$. concolor by for instance the oval form. 


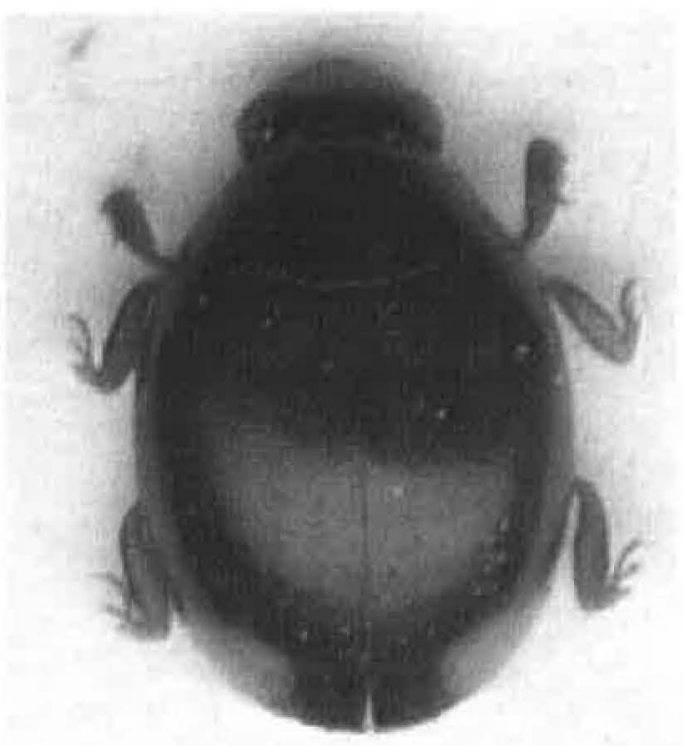

Fig. 3. Hyperaspis pseudopustulata Mulsant, 1853. +

ly thicker and more broad than by $H$. inexpectata and $H$. concolor. The tarsal furrows are more broad by $H$. pseudopustulata, mostly seen from above.The furrow is, further more ending in a small, "tooth like" expansion in the front part which is very weak, mostly lacking by the two other species.

\section{Distribution}

According to the material at my disposal it can be concluded that $H$. reppensis does not occur in the northern countries, most probably not in the Baltic states either (see above). H. pseudopustulata appears in all northern countries and has a wide distributional area from Sk to Lu in Sweden and from $\mathrm{N}$ to $\mathrm{Om}$ in Finland where it should be found even further north. I have seen one Estonian specimen of $H$. pseudopustulata. In the Karelian parts of the former USSR H. pseudopustulata occurs up to Kk. Kantalahti (Fig. 4) H. inexpectata occurs in southern Finland up to the province Ta. In Karelia it has ben recorded from $\mathrm{K} 1$ :Salmi. $H$. concolor occurs in south western

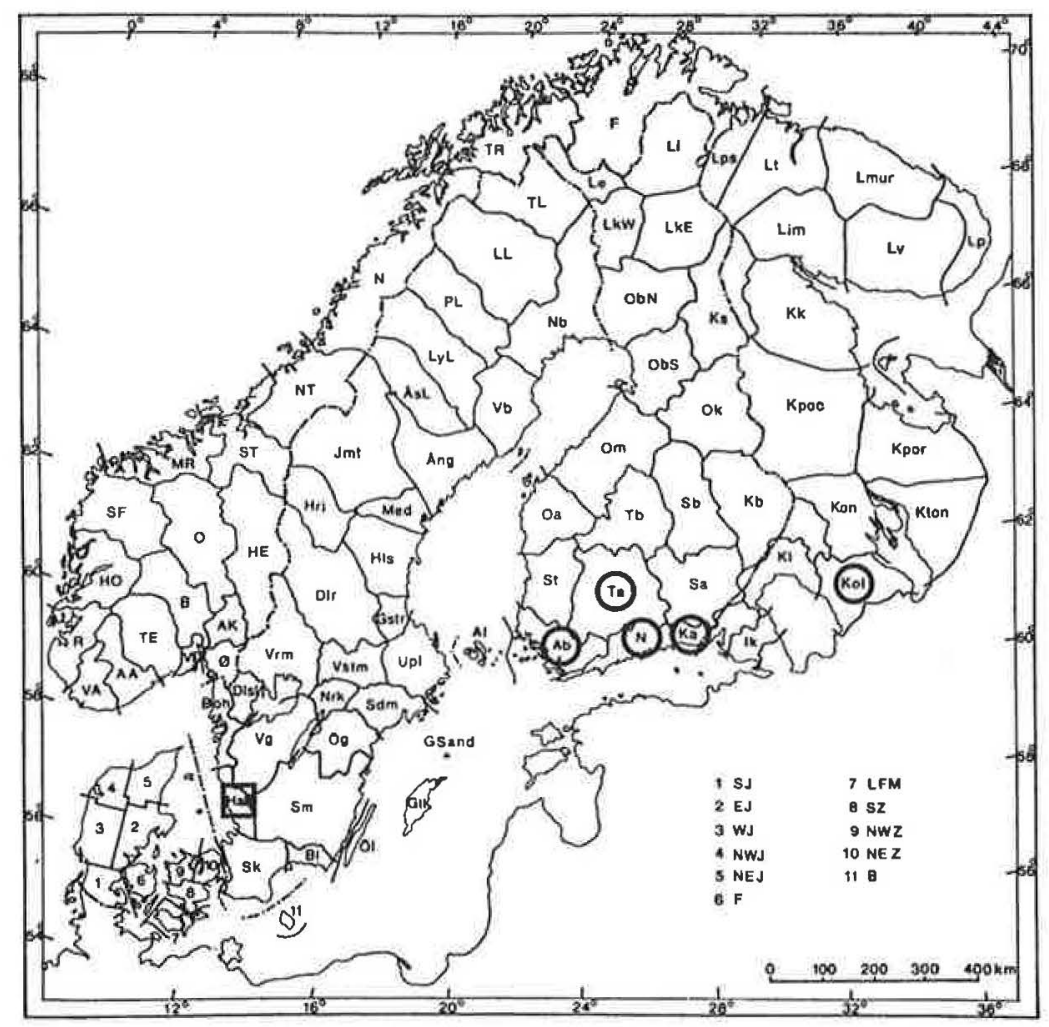

Fig. 4. The distribution of Hyperaspis pseudopustulata following the biogeographical provinces of Sweden, Finland, Norway (Vik, 1992), Denmark (Hansen, 1996) and western Russia (open circles). 


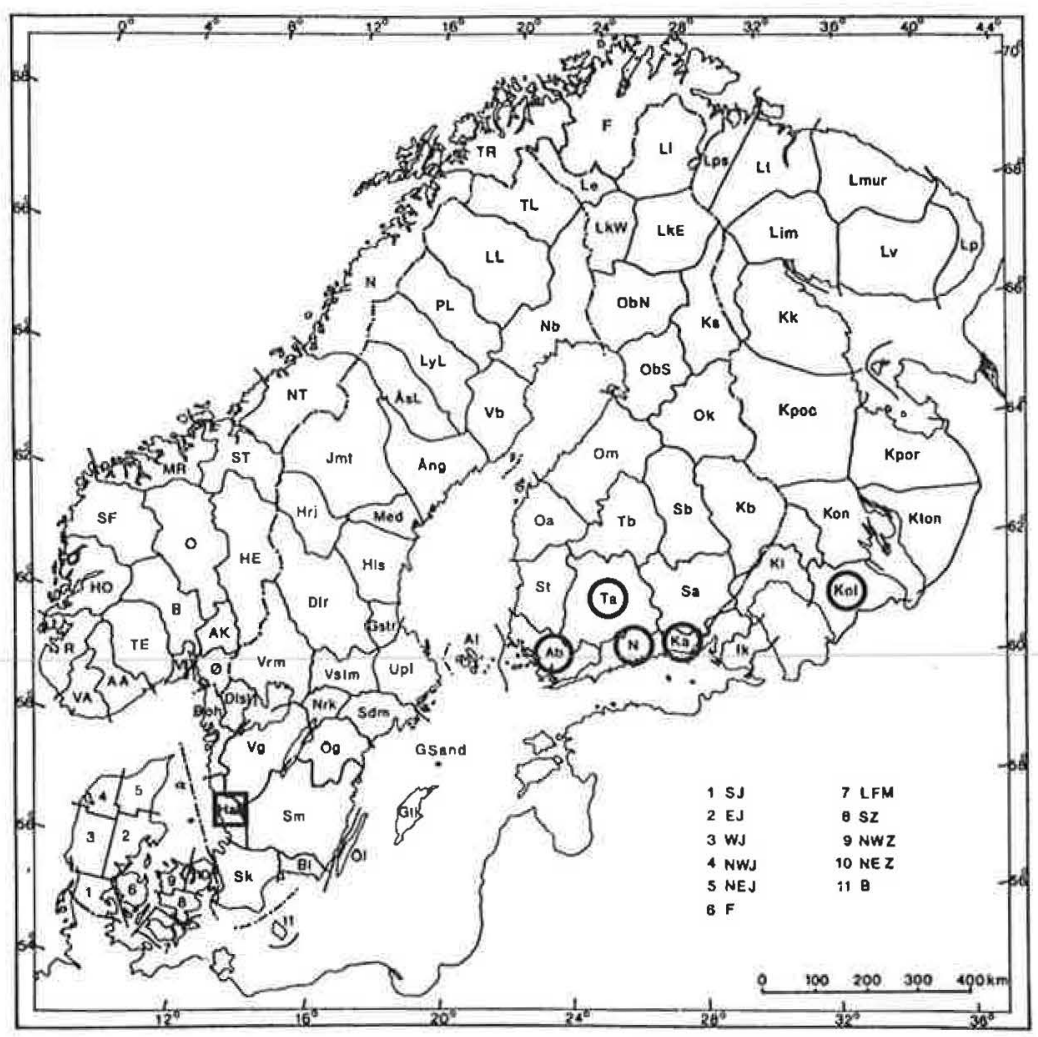

Fig. 5. The distribution of Hyperaspis inexpectata (open circles) and Hyperaspis concolor (open squares) following the biogeographical provinces of Sweden, Finland and western Russia.

Sweden Hl. Fjärås (Fig. 5) and should also be found in Denmark though probably very rarely.

Acknowledgements. I wish to thank the following persons and Institutions for loan of Hyperaspis material. From Sweden: Roy Danielsson Museum of Zoology Lund University, Ted von Proschwitz Göteborg Natural History Museum, Bert Gustafsson Swedish Museum of Natural History Stockholm and Stig Lundberg Luleå. From Finland: Vesa Varis Zoological Museum of the University of Helsinki, Martti Koponen The University of Helsinki, the Department of Applied Zoology, Viikki, Veikko Rinne Zoological Museum of the University of Turku, Ilpo Mannerkoski Järvenpää and Ilpo Rutanen Hyvinkää. Prof. Helmuth Fürsh Ruderting, Germany is specially thanked for valuable donations of comparisson material of the species $H$. reppensis, $H$. campestris and $H$. concolor.Veikko Rinne is also acknowledged for the help with the pictures.

\section{References}

Canepari, C., Fürsch, H. \& Creissel, E. 1985: Dic Hyperaspis-Arten von Mittel-, West- und Südeuropa. Systematik und Verbreitung. - Giorn. Ital. Ent., 2: 223-252.
Clayhills, T. \& Rutanen, I. 1987: Hyperaspis inexpectata found in Finland (Coleoptera, Coccinellidae). - Notulae Entomol. 67: 209.

Fürsch, H. 1992: Familie: Coccinellidae - In: Lohse, G., A. and Lucht, W., H.: Die Käfer Mitteleuropas. 2. Suplementband mit Katalogteil. 167-169 pp.

Günther, V. 1959: Vertreter des Tribus Hyperaspini (Col., Coccinellidae) aus der Tschechoslowakei. - Acta Soc. Entomol. Czech. 56: 255-264.

Hansen, M. 1987: Om mariehönen Hyperaspis pseudopustulata Mulsant, 1853 i Danmark. — Ent. Meddr. 54: 179_ 180.

Hansen, M. 1996: Katalog over Danmarks biller. - Ent. Meddr. 64: 1 \& 2. 164 pp.

Hansen, V. 1969:Biller XXVI. Andet tillægsbind. — Danm. fauna $78: 128 \mathrm{pp}$.

Lindroth, C.H. (ed.) 1960: Catalogus Coleopterorum Fennoscandiae et Daniae. - Lund, 467 pp.

Lucht, W.,L. 1992: Katalogteil. — In: Lohse,G., A. and Lucht, W., H., Die Käfer Mitteleuropas. 2. Suplementband mit Katalogteil. 321 pp.

Lundberg, S. 1986: Catalogus Coleopterorum Sueciae. Stockholm, $155 \mathrm{pp}$.

Lundberg, S. 1995: Catalogus Coleopterorum Sueciae (vers. 2). Stockholm

Vik, A., 1992: Catalogus Coleopterorum Norvegica. — Larvik, $1+169 \mathrm{pp}$. 